\title{
The Euphorbiaceae (Spurge Family) in Bogor Botanic Gardens, Indonesia: Diversity, conservation and utilization
}

\author{
ESTI MUNAWAROH ${ }^{1, \vartheta}$, YUZAMMI $^{1, \bullet \vee}$, Y. PURWANTO ${ }^{2, \bullet \bullet \vee}$ \\ ${ }^{1}$ Research Center for Plant Conservation and Botanic Gardens, Indonesian Institute of Sciences. Jl. Ir. H. Juanda 13, Bogor 16122, West Java, Indonesia. \\ Tel./fax.: +62-251-8322187, ^email: munawaroh.esti@yahoo.com; •vyuzammi@yahoo.co.id \\ ${ }^{2}$ Research Center for Biology, Indonesian Institute of Sciences. Jl. Raya Jakarta Bogor Km. 46, Cibinong, Bogor 16911, West Java, Indonesia \\ $\vee v$ email: purwanto.lipi@gmail.com
}

Manuscript received: 11 February 2020. Revision accepted: 6 October 2020

\begin{abstract}
Munawaroh E, Yuzammi, Purwanto Y. 2020. The Euphorbiaceae (Spurge Family) in Bogor Botanic Gardens, Indonesia: Diversity, conservation and utilization. Biodiversitas 21: 5021-5031. Euphorbiaceae (Spurge family) is the fourth largest family worldwide, consists of 1,354 species and 91 genera. The family is also a part of the Bogor Botanic Gardens collections. The Gardens has evolved to fulfill its mission through five principal functions: conservation, research, education, tourism, and environmental services. The aims of this study are to reveal the diversity, conservation, and its potential in the Bogor Botanic Gardens. This research was based on direct observation of all members of Euphorbiaceae family in the Gardens, as well as Registration Unit and the Garden's catalog which were observed for more than 10 years. The Gardens collected 39 genera, 71 species, and 136 specimens where 91 specimens are trees, 38 specimens are shrubs, three specimens are climbers and four specimens are succulents. Most of the collections are native to Indonesia 75.91\% (103 specimens) and only 33 specimens (24.09\%) from overseas. Amongst native collections have dominated from Jawa 25.54\% (34 specimens), Sumatra 24.08\% (33 specimens). The others are from Sulawesi 9.48\% (13 specimens), Kalimantan 7.29\% (10 specimens), Maluku 6.56\% (9 specimens), Papua 2.28\% (three specimens), and Nusa Tenggara Timur $0.72 \%$ (one specimen). Many species of the family have potentially developed as traditional medicinal plants (11 species), ornamental plants (16 species), spices and vegetable (two species), timbers (14 species), rubber plants (one species), source of energy (two species) and toxic (six species). Several old collections have retained at the Gardens that aged over 75 years, such as Mallotus philippensis (Lam.) Mull. Arg. forma mollis, Acalypha wilkesiana Mull. Arg., Acalypha hispida Burm. var. sanderi (N.E.Br.) J. J. Sm., Acalypha wilkesiana Mull. Arg. forma Montana, Sapium aucuparium Jacq. and Ricinodendron heudelotii (Bail.) Heckel. A map of planting point of the Euphorbiaceae collections is provided.
\end{abstract}

Keywords: Bogor Botanic Gardens, conservation, diversity, Euphorbiaceae, potential

\section{INTRODUCTION}

Forests are important repositories of terrestrial biodiversity and play a key role in influencing socioecological and cultural attributes of human societies including livelihood activities of traditional societies living in these areas (Hermann 2006; Baboo et al. 2017; Karki et al. 2017). Biodiversity is essential for human survival and economic well being and for the ecosystem function and stability (Singh 2002). Globally, habitat destruction, overexploitation, pollution, and species introduction are identified as major causes of biodiversity loss (UNEP 2001; Bargali et al. 2014, 2015; Mourya et al. 2019). The existence of a species in nature largely depends on its regeneration under varied environmental conditions like forest floor conditions; nutrient use efficiency of species and cycling as well as decomposition processes (Bargali 1994, 1995, 1996; Bargali et al. 1992, 1993; Bargali and Singh 1997). These pressures have put the species from their natural habitat to the ex-situ conserving conditions so that the species may be conserved for future generations.

Bogor Botanic Gardens is an ex-situ plant conservation area that has documented collections and its arranged based on classification, bioregion, thematic pattern, or a combination of these patterns. It was founded on May 18, 1817 by G.G. Reinwardt, a botanist from Germany (Hendrian and Witono 2011). As an ex-situ conservation of plant species is an effort to preserve, research and use plants sustainably outside their natural habitat. In more specific the Gardens task and function are to carry out exsitu plant conservation including to conduct research, to utilize and to develop potential of its collections in sustainable manner, and also to develop ecosystem services. One of the Gardens collections which have potential for further development is the Euphorbiaceae (spurge family).

The Euphorbiaceae is one of the largest and most diverse families of flowering plants, consists of ca. 340 genera and nearly 9000 species worldwide, commonly distributed in tropical regions in the world (Wurdack et al. 2004; Fayed et al. 2019). Most of the members are herbs but some, particularly in the tropics, are trees or shrubs or succulents or even cacti-like (Rahman and Akter 2013). From an ecological point of view, the existence of Euphorbiaceae is of utmost importance for ecosystem balancing. The members of this family are mostly tolerant of various environmental conditions, notably in open and dry areas (Polosakan and Alhamd 2012). Moreover, some 
of the members can be used as traditional medicine, food, ornamental plant, poison, rubber, and material for construction (Djarwarningsih 2007). However, the potential of the Euphorbiaceae collection, particularly in the Gardens, for conservation and economic purposes has not yet been fully explored. Therefore, this study aimed to reveal the diversity of the Euphorbiaceae species at the Bogor Botanic Gardens, to conserve it and to list the species with particular potential such as for medicine, ornamental, food, rubber, toxic and material for construction.

\section{MATERIALS AND METHODS}

The materials used in this study are based on the cultivated plant at the Bogor Botanic Garden, Indonesian Institute of Sciences, Indonesia. The research was conducted from 2015-2018. The method used was direct observation of all the Euphorbiaceae collections, both are planted in the field and in the nursery. The observations encompassed planting and maintenance of the Euphorbiaceae collections in the Garden and how the collections could grow well for ex-situ conservation purposes. Besides, the data were also obtained from various sources in order to support this study viz. Registration Unit of BBG (accession data, planting data, and death record data), the Garden's catalog, and literature. Ethnobotany study was obtained from direct observation during field works and from other sources.

\section{RESULTS AND DISCUSSION}

\section{The diversity of Euphorbiaceae at the Bogor Botanic Gardens}

Recent study on molecular phylogenetic have been segregated the Euphorbiaceae sensu lato (s.l.) into five families by many taxonomists, for instance, Webster (1994), Wurdack et al. (2004), Fayed et al. (2019), based on the most advance molecular taxonomy in conjunction with the morphology. These five families split off from Euphorbiaceae s.l. are Phyllanthaceae, Putranjivaceae, Pandanaceae, Picrodendraceae, and Euphorbiaceae sensu stricto (s.s.).
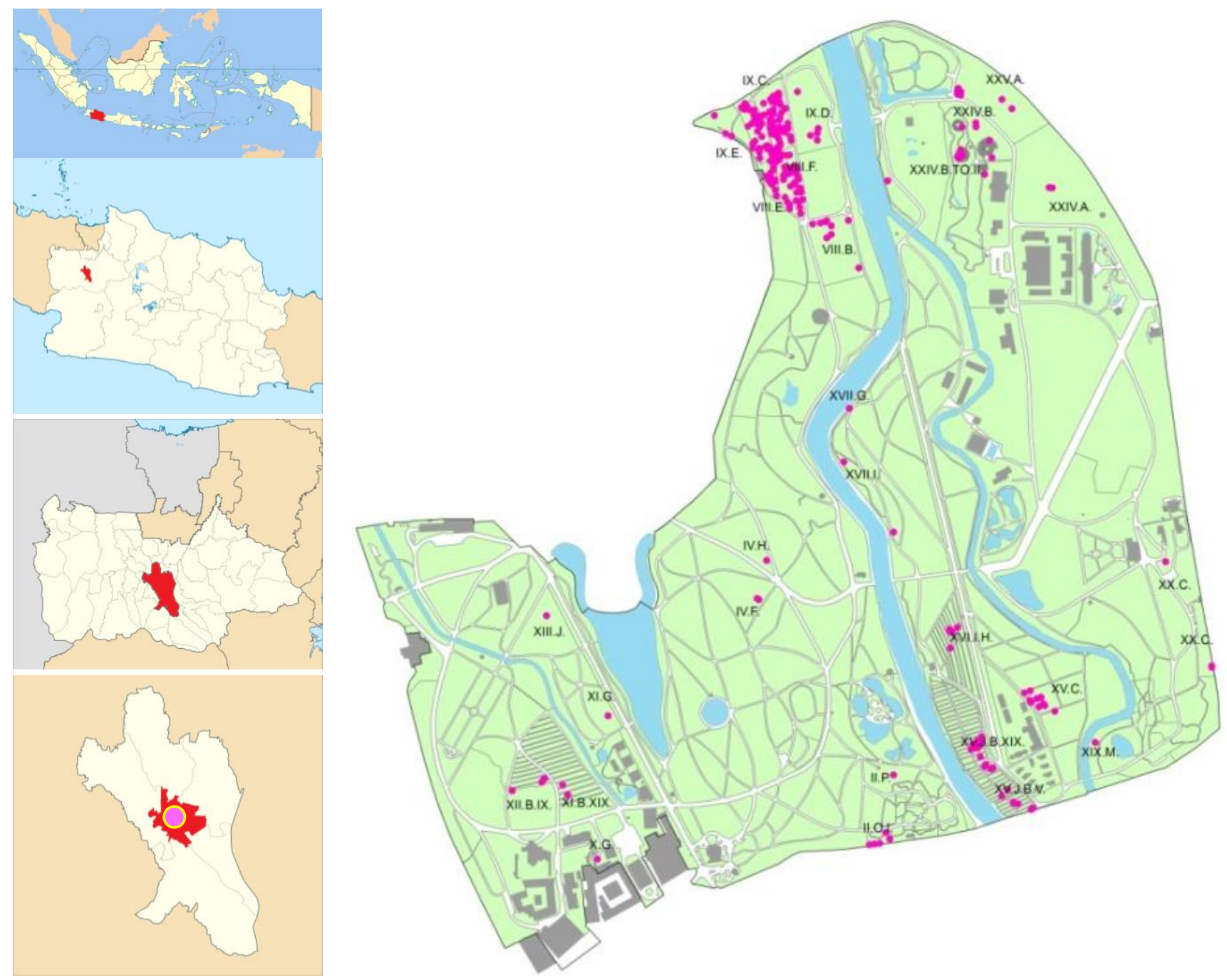

Figure 1. Euphorbiaceae collections planted at the Bogor Botanic Gardens of Bogor Tengah Sub-district, Bogor City, West Java, Indonesia (red-purple tiny dots) 
Table 1. Euphorbiaceae collections at the Bogor Botanic Gardens, West Java, Indonesia

\begin{tabular}{|c|c|c|c|c|c|c|}
\hline Genera & Species & Habitus & Origin & $\begin{array}{c}\text { Planting } \\
\text { year }\end{array}$ & $\begin{array}{c}\text { No. of } \\
\text { spec. }\end{array}$ & Bed numbers \\
\hline \multirow[t]{7}{*}{ Acalypha } & hispida Burm.F & $\mathrm{S}$ & India & 1993 & 1 & XVI.I.G.32 \\
\hline & $\begin{array}{l}\text { hispida Burm.F var. sanderi (N.E.Br.) J.J } \\
\text {.Smith }\end{array}$ & $S$ & India & 1924 & 2 & XVI.I.I.1.1a \\
\hline & wilkesiana Müll Arg. & S & W. Java & 1924 & 1 & XIX.I.D.16 \\
\hline & wilkesiana Müll Arg. & $S$ & Maluku & 1924 & 2 & XIV.G.11-11a \\
\hline & wilkesiana Müll Arg. & $S$ & Australia & 1924 & 1 & XVI.I.G.5 \\
\hline & wilkesiana Müll Arg. forma illustris & $S$ & W. Java & 1924 & 1 & XXIV.A.XII.20 \\
\hline & wilkesiana Müll Arg. forma montana & $\mathrm{S}$ & W. Java & 1924 & 1 & XXIVA.VI.15 \\
\hline \multirow[t]{2}{*}{ Alchornea } & rugosa (Lour) Müll Arg. & $S$ & W. Java & 2013 & 1 & VIII.F. 113 \\
\hline & & & & & 1 & XI. B.XV.135 \\
\hline Aleurites & moluccanus (L.) Willd. & $\mathrm{T}$ & NTT & 1995 & 1 & IX.A.92a \\
\hline Balakata & baccata (Roxb.) Esser & $S$ & $\begin{array}{l}\text { Sumatra: } \\
\text { Lampung }\end{array}$ & 2005 & 1 & IX.E.91 \\
\hline \multirow[t]{2}{*}{ Blumeodendron } & tokbrai (Blume) Kurz & $\mathrm{T}$ & S. Kalimantan & 1924 & 1 & IX.C. 144 \\
\hline & & $\mathrm{T}$ & Sumatra: Aceh & 1924 & 1 & IX.A.98 \\
\hline Botryophora & geniculata (Miq.) Beumee ex Airy Shaw & $\mathrm{T}$ & Sumatra:Lampung & 2005 & 1 & IX.C.186 \\
\hline Cephalomappa & malloticarpa J.J. Smith & $\mathrm{T}$ & W. Java & 2005 & 2 & VIII.F.50-50a \\
\hline Cleidion & spiciflorum (Burm. f.) Merr. & $\mathrm{T}$ & W. Java & 1997 & 2 & IX.A.88-88a \\
\hline \multirow[t]{3}{*}{ Codianum } & variegatum Blume & S & W. Sumatra & 2007 & 1 & II.P. 124 \\
\hline & & S & Sumatra & 2007 & 1 & XXIV.A.VII.26 \\
\hline & variegatum Blume var. celebica & $S$ & S.E. Sulawesi & 2012 & 1 & XV.J.B.XXIX. 22 \\
\hline \multirow[t]{5}{*}{ Croton } & argyratus Blume & $\mathrm{T}$ & Java: Banten & 1965 & 1 & XV.C.64a \\
\hline & & $\mathrm{T}$ & S. Kalimantan & 1995 & 2 & IXC.154. XVI.IE. 15 \\
\hline & caudatus forma multiglandulosus & W.Cl. & Java & 1965 & 2 & XV.C. $17-17 \mathrm{a}$ \\
\hline & tiglium $\mathrm{L}$. & $\mathrm{T}$ & SE Asia & 1995 & 1 & XVI.I.D.36 \\
\hline & sp. & $S$ & Sumatra:Aceh & 2003 & 1 & IX.C. 174 \\
\hline Elateriospermum & tapos Blume & $\mathrm{T}$ & E.Kalimantan & 2007 & 2 & IX.C.194-195a \\
\hline Endospermum & moluccanum (Teijsm. \&Binn) Becc. & $\mathrm{T}$ & Papua & 2004 & 1 & XXV.B.40 \\
\hline \multirow[t]{5}{*}{ Euphorbia } & lactea Haw & Sc. & SE. India & 1995 & 1 & II.O.I.37 \\
\hline & neriifolia $\mathrm{L}$ & Sc. & SE. India & 2006 & 3 & II.O.I. $47-47 a-47 b$ \\
\hline & pulcherrima (Graham) Willd. ex Klotzsch & $\mathrm{S}$ & Mexico & 1982 & 1 & XXIV.A.II.5 \\
\hline & Tirucalli L. & S & Africa & 1971 & 1 & II.O.I.1 \\
\hline & tithymaloides (L.) Poit & $S$ & W. Java & 2002 & 1 & XXIV.B.XVI.12 \\
\hline \multirow[t]{2}{*}{ Exoecaria } & agallocha $\mathrm{L}$ & S & S. Sumatra & 2009 & 2 & IX.D.310-310A \\
\hline & cochinchinensis Lour. & S & Java & 2007 & 1 & XXIV.B.XVI.10 \\
\hline Galeria & filiformis (Blume) Pax & $\mathrm{T}$ & Sumatra:Lampung & 2006 & 2 & VIII.B. $44-44 a$ \\
\hline Hancea & $\begin{array}{l}\text { subpeltata (Blume) M. Aparicio ex } \\
\text { S.E.C.Sierra, Kulju \& Welzen }\end{array}$ & S & W. Sumatra & 2009 & 1 & VIII.F.94 \\
\hline \multirow[t]{5}{*}{ Hevea } & brasiliensis (Will. Ex A. Juss) Müll Arg. & $\mathrm{T}$ & Brazil & 1996 & 1 & IX.C.132 \\
\hline & & & Sumatra: Jambi & 1996 & 1 & VIII.F.101 \\
\hline & confusa Hemsl. & $\mathrm{T}$ & Guiana & 2004 & 2 & VIII.F.75-75A \\
\hline & pauciflora (spruce ex Benth.) Müll Arg. & $\mathrm{T}$ & Bazil & 1980 & & IX.A. 13 \\
\hline & spruceana (Benth.) Müll Arg. & $\mathrm{T}$ & Brazil & 1980 & 1 & VIII.E. 28 \\
\hline Homonoia & javense (Blume) Müll Arg. & $\mathrm{T}$ & Java & 1982 & 2 & IX.A.26-26a \\
\hline \multirow[t]{2}{*}{ Hura } & crepitans $\mathrm{L}$. & $\mathrm{T}$ & W. Java & 1964 & 1 & XVII.I.79 \\
\hline & polyandra Baill & $\mathrm{T}$ & Mexico & 1983 & 2 & XXV.A.215-215b \\
\hline \multirow[t]{4}{*}{ Jatropha } & curcas L. & S & W. Indies & 1977 & 1 & XXIV.B.XVI.11 \\
\hline & gossypifolia $\mathrm{L}$. & S & Africa & 1977 & 1 & XXIV.B.XVII. 4 \\
\hline & multifida L. & S & W. Java & 1996 & 1 & XXIV.A.XII.13 \\
\hline & podagrica Hook.f. & $S$ & C. America & 1998 & 1 & II.O.VII.42, 124 \\
\hline Joannesia & princeps Vell. & $\mathrm{T}$ & Brazil & 2005 & 1 & IX.C. 172.187 \\
\hline \multirow[t]{6}{*}{ Macaranga } & conifera Müll Arg. & $\mathrm{T}$ & W. Sumatra & 2007 & 3 & $\begin{array}{l}\text { VIII.F. } 100.100 \mathrm{a} \\
\text { 105A.309b }\end{array}$ \\
\hline & gigantea Müll Arg. & $\mathrm{T}$ & S.E. Sulawesi & 1995 & 1 & IX.D. 238 \\
\hline & hypoleuca Müll Arg. & $\mathrm{T}$ & W. Kalimantan & 1996 & 1 & VIII.F.92 \\
\hline & javanica Müll Arg. & $\mathrm{T}$ & Sumatra: Riau & 2009 & 1 & IX.D.311a \\
\hline & pruinosa Müll Arg. & $\mathrm{T}$ & Sumatra: Jambi & 2002 & 2 & IX.C. $166-166 a$ \\
\hline & triloba (Reinw. Ex Blume) Müll Arg. & $\mathrm{T}$ & Sumatra: Jambi & 1998 & 1 & VIII.F.95 \\
\hline Mallotus & borneensis J.J. Sm. & S & W. Kalimantan & 2000 & 1 & IX.C. 163 \\
\hline
\end{tabular}




\begin{tabular}{|c|c|c|c|c|c|c|}
\hline & floribundus (Blume) Müll Arg. & $\mathrm{T}$ & SE Sulawesi & 2014 & 2 & VIII.F.83 \\
\hline & & $\mathrm{T}$ & SE. Sulawesi & 2014 & 1 & IX.C. 158 \\
\hline & & $\mathrm{T}$ & Bangka Island & 1924 & 1 & IX.C.102a \\
\hline & & $\mathrm{S}$ & N. Sulawesi & 2014 & 1 & IX.C.115 \\
\hline & & $\mathrm{T}$ & W. Kalimantan & 1995 & 1 & IX.C.159 \\
\hline & nudiflora (L.) Kulju \& Welzen & $\mathrm{T}$ & W. Sumatra & 1924 & 2 & X.E.40-40a \\
\hline & peltatus (Geisel.) Müll Arg. & $\mathrm{T}$ & W. Java & 1995 & 1 & IX.C.151 \\
\hline & & $\mathrm{T}$ & W. Sumatra & 2002 & 1 & VIII.E.44 \\
\hline & philippensis (Lam.) Mull. Arg. & $\mathrm{T}$ & Philippines & 1981 & 1 & IX.A.81a \\
\hline & philippensis (Lam.) Müll Arg.forma & $\mathrm{T}$ & Philippines & 1922 & 1 & VIII.E.27 \\
\hline & mollis & & & & 1 & IX.C.30a \\
\hline & rufidulus (Miq.) Müll.Arg. & $\mathrm{T}$ & $\begin{array}{l}\text { Sumatra: } \\
\text { Bengkulu }\end{array}$ & 1995 & 1 & IX.C.153 \\
\hline & sp. & S & N. Sulawesi & 2007 & 1 & VIII.E. 165 \\
\hline & & $S$ & W. Sumatra & 2009 & 1 & IX.C.207a \\
\hline Manihot & esculenta Crantz & $S$ & N. Maluku: Ternate & 2008 & 2 & XV.J.B.II.26-26A \\
\hline & & S & S. America & 1997 & 1 & XXIV.B.XVII.2 \\
\hline Melanolepis & multiglandulosa Reich.f. & & N. Sulawesi & 1998 & 2 & X.A.96.X.A.92.93 \\
\hline Neoscortechina & kingii (Hook. f) Pax \& Hoffm & $\mathrm{T}$ & W. Java & 1080 & 2 & IX.A.6-6a \\
\hline Omphalea & papuana Gage & W.Cl. & Papua & 1980 & 1 & XVII.G.122 \\
\hline Paracroton & pendula (Hassk) Airy Shaw & $\mathrm{T}$ & W. Sumatra & 2008 & 4 & IX.A.104-104a.b.c \\
\hline & & $\mathrm{T}$ & N. Sulawesi & 2002 & 2 & IV.F.169-169a \\
\hline Pimelodendron & amboinicum Hassk & $\mathrm{T}$ & Maluku: Ambon & 1964 & 1 & VIII.F.76a \\
\hline & & $\mathrm{T}$ & - & 2003 & 2 & IXC167a,XII.B.IX.3 \\
\hline & & $\mathrm{T}$ & SE. Sulawesi & 2012 & 1 & XXIV.B.56 \\
\hline & & $\mathrm{T}$ & SE. Sulawesi & 2012 & 1 & XV.J.B.XIX. 21 \\
\hline & macrocarpum J.J. Smith & $\mathrm{T}$ & N. Sumatra & 2009 & 1 & IX.C.127 \\
\hline & & & & 2006 & 1 & XXIV.B.53 \\
\hline & zoanthogyne J.J. Smith & $\mathrm{T}$ & Kalimantan & 1981 & 1 & XXIV.A.65 \\
\hline Reutealis & trisperma (Blanco) Airy Shaw & $\mathrm{T}$ & W. Java & 1964 & 4 & XXV.A.243a-d \\
\hline Ricinodendron & heudelotii (Bail.) Heckel & $\mathrm{T}$ & Africa & 1965 & 1 & IX.A86 \\
\hline & & $\mathrm{T}$ & W. Java & 1965 & 2 & IX.C.201-201a \\
\hline Sapium & aucuparium Jacq & $\mathrm{T}$ & W. Indies & 1964 & 1 & XX.C.71 \\
\hline Shirakiopsis & Indica (Willd) Esser & $\mathrm{T}$ & S. Sulawesi & 1996 & 1 & VIII.E.38 \\
\hline & & $\mathrm{T}$ & W. Java & 1993 & 2 & XXIV.34-34a \\
\hline Spathiostemon & javensis (Blume) Müll Arg. & $\mathrm{T}$ & Java & 1982 & 2 & IX.A.26-26a \\
\hline Strophioblanca & fimbricalyx Boerl. & $\mathrm{T}$ & Maluku: Ambon & 1996 & 2 & VIII.F.43-43A \\
\hline Sumbaviopsis & albicans (Blume) J.J.Sm. & $\mathrm{T}$ & Java & 1988 & 2 & VIII.F.81;IX.A.95 \\
\hline Suregada & glomerulata (Blume) Baill. & $\mathrm{T}$ & Java & 1996 & 2 & VIII.F.4, IX.C.124 \\
\hline & & $\mathrm{T}$ & Sumatra: Bengkulu & 1996 & 2 & VII.E.41.,47 \\
\hline & & $\mathrm{T}$ & W. Sumatra & 1924 & 2 & X.E.40-40a \\
\hline Trigonostemon & anomalus Merr. & S & Papua & 2009 & 1 & XV.J.B.XX.7 \\
\hline & & $S$ & W. Java & 1981 & 1 & XII.B.VIII.57 \\
\hline & longifolius Baill & $\mathrm{S}$ & W. Sumatra & 2002 & 2 & XI.B.XVII.270-270a \\
\hline & serratus Blume & $\mathrm{T}$ & Sumatra: Jambi & 2003 & 1 & XI.G.161 \\
\hline Vernicia & montana Lour. & $\mathrm{T}$ & W. Java & 1989 & 1 & XX.C.97-97a \\
\hline
\end{tabular}

Note: T: Tree, S: Shrub, W.Cl.: Wood Climber, Sc: Succulent. Sources: The Registration Unit database and the Gardens Catalogue (Sari et al. 2010)

In general, the Euphorbiaceae s.l. collections at the Bogor Botanic Gardens (BBG) have been cultivated since 1922. Most of the collections were collected throughout the Indonesian lowland forests, some of them were obtained from overseas via seed exchange among other botanic gardens in the world. The number of genera and species presented in Euphorbiaceae s.l. as cited in the Garden's Catalogue (Sari et al. 2010) were 54 genera, 136 species (eight are still spp.), and 235 specimens in total. Since the family has been split into five families thus an evaluation through the Gardens' collections resulted in 39 genera, 71 species, and 136 specimens (Table 1). Some of the members have separated to be Phyllantaceae family such as genera Actephila, Antidesma, Aporosa, Baccaurea, Bischofia, Breynia, Bridelia, Cleistanthus, Galearia, Glochidion, Margaritaria, Phyllanthus, and Sauropus. Moreover, the genus Drypetes segregated into Putranjivaceae family and Galearia into Pandanaceae family. As can be seen in Figure 1, the members of Euphorbiaceae (here used only Euphorbiaceae for the rest of this paper) have been cultivated at the Bogor Botanic Gardens in several bed numbers. However, it is suggested to do revision on the Garden's Catalogue as well as name tags on the Gardens collections. 


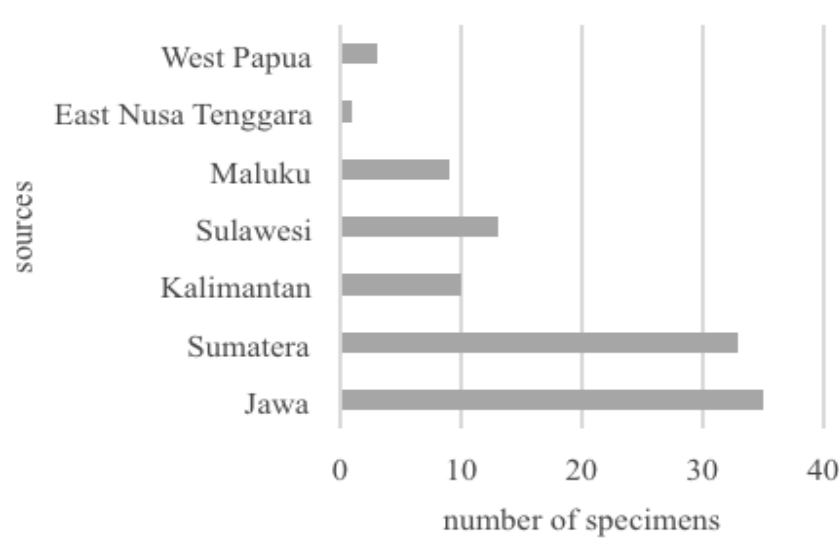

Figure 3. The number of Euphorbiaceae specimens has cultivated at the Bogor Botanic Gardens, West Java, Indonesia collected throughout Indonesian forests

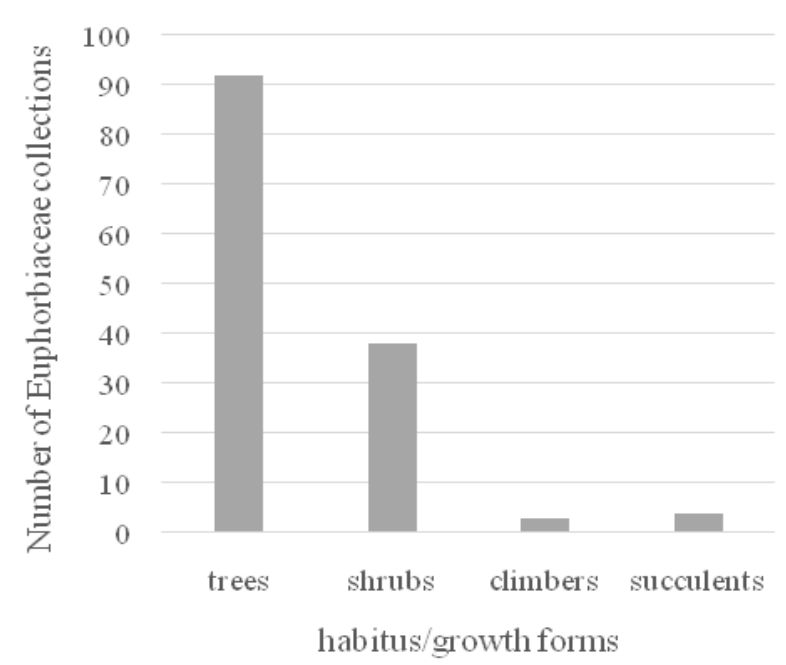

Figure 2. The Euphorbiaceae collections at the Bogor Botanic Gardens, West Java, Indonesia based on habitus

\section{Habitus of the Euphorbiaceae family}

The Euphorbiaceae family displays remarkable range of vegetative growth from woody plant to succulent. The growth forms represent at the BBG including tree, shrub, vines/climber, and succulent. In this case, the number of trees of Euphorbiaceae collections at the BBG is 92 specimens, of which 56 specimens have stem diameter over than $25 \mathrm{~cm}$ (from 20 genera and 24 species), such as Aleurites moluccanus (L.) Willd., Blumeodendron tokbrai (Blume) Kurz, Cephalomapha malloticarpa J.J. Smith, Croton argyratus Blume, Endospermum moluccanum (Teijsm. \& Binn), Hevea brasiliensis (Will. Ex A. Juss) Müll Arg., H. confuse Hemsl., Joanesia princeps Vell., Macaranga conifer Müll Arg., M. gigantea Müll Arg., M. triloba Reinw. Ex Blume) Müll Arg., Melanolepis

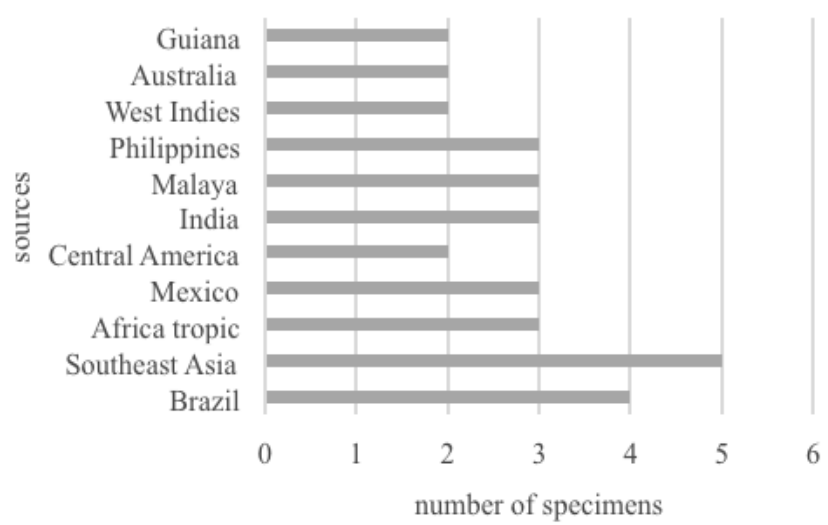

Figure 4. The number of Euphorbiaceae specimens has cultivated at the Bogor Botanic Gardens, West Java, Indonesia obtaining from overseas

multiglandulosa Reich.f., Neoscortechina kingie (Hook. f) Pax \& Hoffm, Pimelodendron amboinicum Hassk, Reutalis trisperma (Blanco) Airy Shaw, Rhichinodendron heudelotii (Bail.) Heckel, Sapium aucuparium Jacq, Shirakiopsis indica (Willd) Esser, Strophioblanchia fimbricalyx Boerl., Sumbaviopsis albicans (Blume) J.J.Sm., Suregada glomerulata (Blume) Baill. and Vernicia Montana Lour. The rest of Euphorbiaceae collections growth forms at the Gardens are shrubs (38 specimens), climbers (3 specimens), and succulents (4 specimens) (Figure 2).

It should be noted that slightly over $60 \%$ of the tree's forms having stem diameter more than $25 \mathrm{~cm}$ which indicated the Gardens enable to maintain their collections in excellent condition. Thus, this indicates that ex-situ conservation of the Euphorbiaceae family at the BBG has been successful, in accordance with one of its functions.

\section{Source locations of the collections}

As mentioned above, the number of specimens of the Euphorbiaceae in the Gardens is 136 specimens of which 104 specimens mostly obtained from flora exploration throughout Indonesian forests. There are 35 specimens (25.54\%) from Jawa, Sumatra is represented by 33 specimens $(24.08 \%)$, Sulawesi is represented by 13 specimens $(9.48 \%)$, Kalimantan is represented by 10 specimens (7.29\%), Maluku is represented by nine specimens $(6.56 \%)$, West Papua is represented by three specimens (2.18\%) and East Nusa Tenggara is represented only one specimen $(0.72 \%)$. Meanwhile, the Gardens also cultivated a number of specimens of the Euphorbiaceae from overseas, including Brazil (four specimens), Southeast Asia (five specimens), Africa tropic (three specimens), Mexico (three specimens), Central America (two specimens), India (three specimens), Malaya (three specimens), Philippines (three specimens), West Indies (two specimens), Australia (two specimens) and Guiana (two specimens) (Table 2, Figure 4). 
Table 2. The number of the Euphorbiaceae family cultivated at the Bogor Botanic Gardens, West Java, Indonesia from overseas, together with the planting year

\begin{tabular}{|c|c|c|c|}
\hline Origin & Species name & Planting year & Number of specimens \\
\hline Australia & Acalypha wilkesiana Müll Arg. & 1924 & 2 \\
\hline \multirow[t]{4}{*}{ Brazil } & Hevea brasiliensis (Will. Ex A. Juss) Müll Arg. & 1996 & 1 \\
\hline & Hevea pauciflora (spruce ex Benth.) Müll Arg. & 1980 & 1 \\
\hline & Hevea spruceana (Benth.) Müll Arg. & 1980 & 1 \\
\hline & Jatropha princeps Vell. & 2005 & 1 \\
\hline \multirow[t]{2}{*}{ Central America } & Jatropha podagrica Hook.f. & 1998 & 2 \\
\hline & Manihot esculenta Crantz & 1997 & 1 \\
\hline Guiana & Hevea confusa Hemsl & 2004 & 2 \\
\hline \multirow[t]{2}{*}{ India } & Acalypha hispida Burm. F. & 1993 & 1 \\
\hline & Acalypha hispida Burm. var. sanderi (N.E.Br.) J. J. Smith & 1924 & 2 \\
\hline \multirow[t]{2}{*}{ Malaya } & Acalypha wilkesiana Mull. Arg. forma montana & 1924 & 2 \\
\hline & Codiaeum variegatum Blume & 1995 & 1 \\
\hline \multirow[t]{2}{*}{ Mexico } & Euphorbia pulcherrima (Grahmen) Wild ex Klotzsch & 1982 & 1 \\
\hline & Hura polyandra Baill. & 1983 & 2 \\
\hline \multirow{2}{*}{ Philippines } & Mallotus philippensis (Lam.) Müll Arg. & 1981 & 1 \\
\hline & Mallotus philippensis (Lam.) Müll Arg.forma mollis & 1922 & 2 \\
\hline \multirow[t]{3}{*}{ Southeast Asia } & Croton tiglium $\mathrm{L}$. & 1995 & 1 \\
\hline & Euphorbia lactea Haw. forma cristata & 1995 & 1 \\
\hline & Euphorbia neriifolia $\mathrm{L}$ & 2006 & 3 \\
\hline \multirow[t]{3}{*}{ Tropic Africa } & Euphorbia tirucali L. & 1971 & 1 \\
\hline & Jatropha gossypifolia $\mathrm{L}$. & 1977 & 1 \\
\hline & Ricinodendron heudelotii (Bail.) Heckel & 1965 & 1 \\
\hline \multirow[t]{2}{*}{ West Indies } & Jatropha curcas L. & 1977 & 1 \\
\hline & Sapium aucuparium Jacq. & 1964 & 1 \\
\hline
\end{tabular}

Based on Registration Unit Data of BBG recorded that Mallotus philippensis (Lam.) Mull. Arg. forma mollis was introduced to the Gardens from the Philippines in 1922. In the following next two years (1924) three species were again introduced to the Gardens viz. Acalypha wilkesiana Mull. Arg. (Australia), Acalypha hispida Burm. var. sanderi (N.E.Br.) J. J. Sm (India) and Acalypha wilkesiana Mull. Arg. forma montana (Malaya). From 1964 to 1983, the director of the Gardens visited many botanic gardens in the world and brought several Euphorbiaceae collections such as, Jatropha gossypifolia L., Euphorbia tirucali L., and Ricinodendron heudelotii (Bail.) Heckel (Africa tropic), Sapium aucuparium Jacq. and Jatropha curcas L. (West Indies), Hevea pauciflora (spruce ex Benth.) Muell. Arg., Hevea spruceana (Benth.) Mull. Arg. (Brazil), Euphorbia pulcherrima (Grahmen) Wild ex Klotzsch and Hura polyandra Baill. (Mexico). From 1990 to 2006, nine species have been added to the Gardens' collections from overseas that were Acalypha hispida Burm.f. (India), Codiaeum variegatum Blume (Malaya), Croton tiglium L., Euphorbia lactea Haw. forma cristata and Euphorbia neriifolia L. (Southeast Asia), Hevea brasiliensis (Will. ex A. Juss) Mull. Arg. and Jatropha princeps Vell. (Brazil), Jatropha podagrica Hook.f. and Manihot esculenta Crantz. (Central America), Hevea confusa Hemsl. (Guiana) (Tabel 2). In addition, the Euphorbiaceae collections have increased from 1970 to 2005 through seed exchanged programs between BBG and other botanic gardens around the world. However, this program had been discontinued since 2007 until now. Hence, additional collections usually donated from overseas.

\section{The age of Euphorbiaceae collections at the BBG}

Based on the age of Euphorbiaceae collections are divided into six groups (Figure 5), viz. the ages of 1-10 years (four genera, six species, seven specimens), the ages of 11-20 years (20 genera, 31 species, 55 specimens), the ages of 21-30 years (12 genera, 18 species, 27 specimens), the ages of $31-40$ years (11 genera, 12 species, 21 specimens), the ages of 41-50 years (two genera, three species, three specimens) and the ages of over 50 years (eight genera, 13 species, 24 specimens). The age of 11-20 years is the greatest number of specimens among others, because flora explorations throughout Indonesian forests have been extensively carried out during those years. Moreover, the policy of the director of BBG strongly supported this activity, in accordance with other government institutions collaboration, such as forestry.

The Euphorbiaceae collections that have aged over 50 years old grew well in BBG until now, such as Acalypha grandis Benth., A. hispida Burm.f, A. wilkesiana Müll. Arg., Alchornea rugosa (Lour.) Müll.Arg., Blumeodendron tokbrai (Blume) Kurz, Hura crepitans L., Mallotus floribundus (Blume) Müll. Arg. M. rufidulus (Miq.) Müll.Arg., M. philippensis (Lam.) Müll. Arg. forma mollis, Pimelodendron amboinicum Hassk, Recinodendron heudelotii (Bail.) Heckel. This because the collections have well maintained and supported with suitable environmental factors as well. 


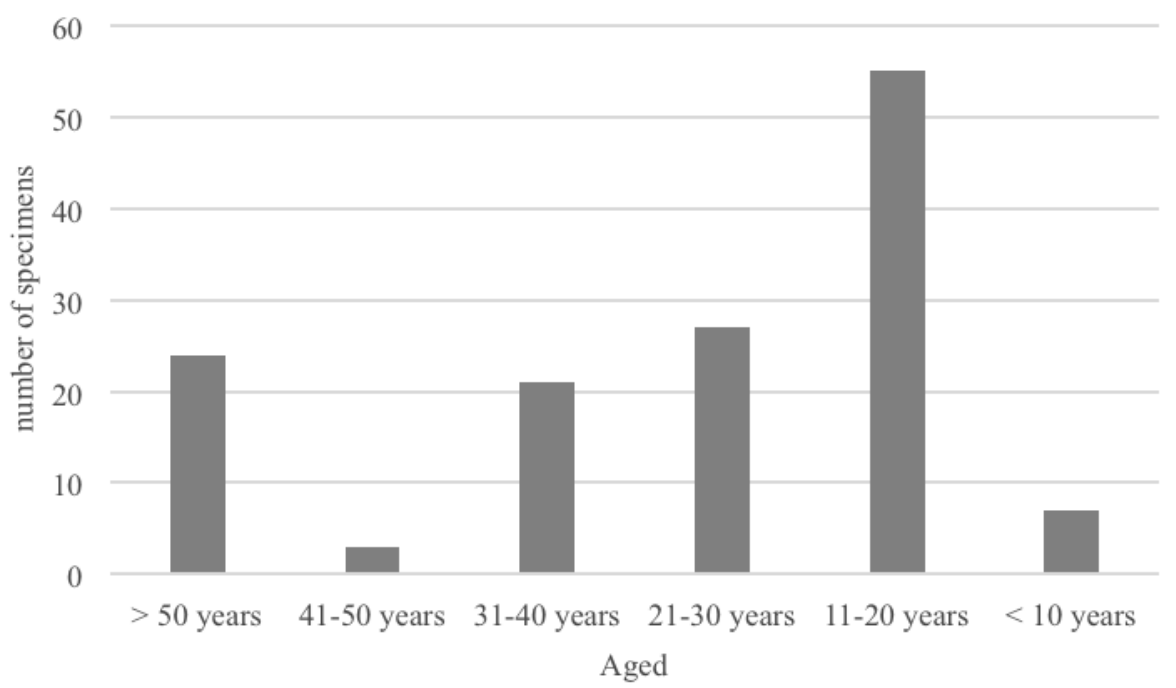

Figure 5. The age of Euphorbiaceae collections at the Bogor Botanic Gardens, West Java, Indonesia

\section{Conservation status}

Joannesia princeps Vell, Pimelodendron amboinicum Hassk, and Cleidion spiciflorum (Burm.f.) Merr. are considered as Vulnerable (VU) based on IUCN (2001). The other species, Alchornea rugosa (Lour) Müll.Arg, Balakata baccata (Roxb.) Esser, Homonoia javensis (Blume) Müll. Arg. and Suregada glomerulata (Blume) Baill., are recognized Least Concern (LC) and Not Evaluated (NE) for Macaranga javanica (Blume) Müll. Arg.

\section{Uses and potential of Euphorbiaceae collections at BBG}

Indonesian people have been used in various plant species for their daily life. Each of the communities has different knowledge to manage and to use of plant diversity which grew in their surrounding homes. These differences have been influenced by the level of cultures, the geographical and ecosystem conditions, the external communities' impact, and the effects of climate changed.

Many species in Euphorbiaceae family have been used by Indonesian people as ingredients of traditional medicines, as foodstuffs, as building materials, as energy source and firewoods, as ornamental plants and other necessities. Almost all parts of the plant have been used, for example, root, stem, bark, leaf, flower, fruit, and seed (Djarwarningsih 2007). Euphorbiaceae collections at the BBG which have potential economic as followed (Table 3): as traditional medicines (11 species), as ornamental plants (16 species), as ingredients and vegetables (two species), as natural dyes for woven cloth (three species), as building materials (14 species), as a source of energy (two species) and as toxics (six species).

\section{Traditional medicines}

There are 11 species (Acalypha wilkesiana, Hevea brasiliensis, Jatropha curcas, J. gossypifolia, J. multifida, J. podagrica, Joannesia princeps, Macaranga gigantea, $M$. triloba, M. hypoleuca, and Ricinodendron heudelotii) are found at the BBG that can be used as traditional medicines (Table 4). These are usually applied to cure several diseases such as eczema, stroke, rheumatism, wound, toothache, swelling, itching, indigestion, gout, acne, cough, and malaria. In addition, J. gossypifolia contains several chemical compounds such as, fat acid, glucose, alkaloid, amino acid, coumarin, steroid, flavonoid, lignan, protein, saponin, tannin, and terpenoid that can relieve the symptoms of eczema, itching, wound and diarrhea (Oduola et al. 2005; Ogundare 2007; Capobianco et al. 2009), while J. multifida is known to heal wounds, swelling, eczema, and indigestion (Anonymous 2020). Moreover, Tchoundjeu and Atangana (2006) mentioned that $R$. heudelotii can be used to heal cough, malaria, stomach-ache, and rheumatism.

It is noted that four species (A. wilkesiana, $H$. brasiliensis, J. gossypifolia, and J. multifida) would be the best remedy for eczema (Gotep et al. 2010). A mix of two kinds of species can be used to heal several diseases, for example: swelling (a mix of J. multifida and M. gigantea), rheumatic (a mix of $H$. brasiliensis and $R$. heudelotii), and digestive disorders (a mix of J. multifida and $R$. heudelotii). Peng et al. (2011) stated that leaf decoction of $H$. brasiliensis is used for stroke treatment, while acne can be treated by pounded a leaf of $M$. triloba then smeared it. Moreover, Batin and Carandang (2010) mentioned that the sap of J. curcas can be cure toothache by dripping it. 
Table 3. The potential of species Euphorbiaceae cultivated at the Bogor Botanic Gardens, West Java, Indonesia for use as medicines, as ornamentals, as vegetables, as ingredients, as dyes, as constructions, as rubbers, as sources of energy, and as toxics

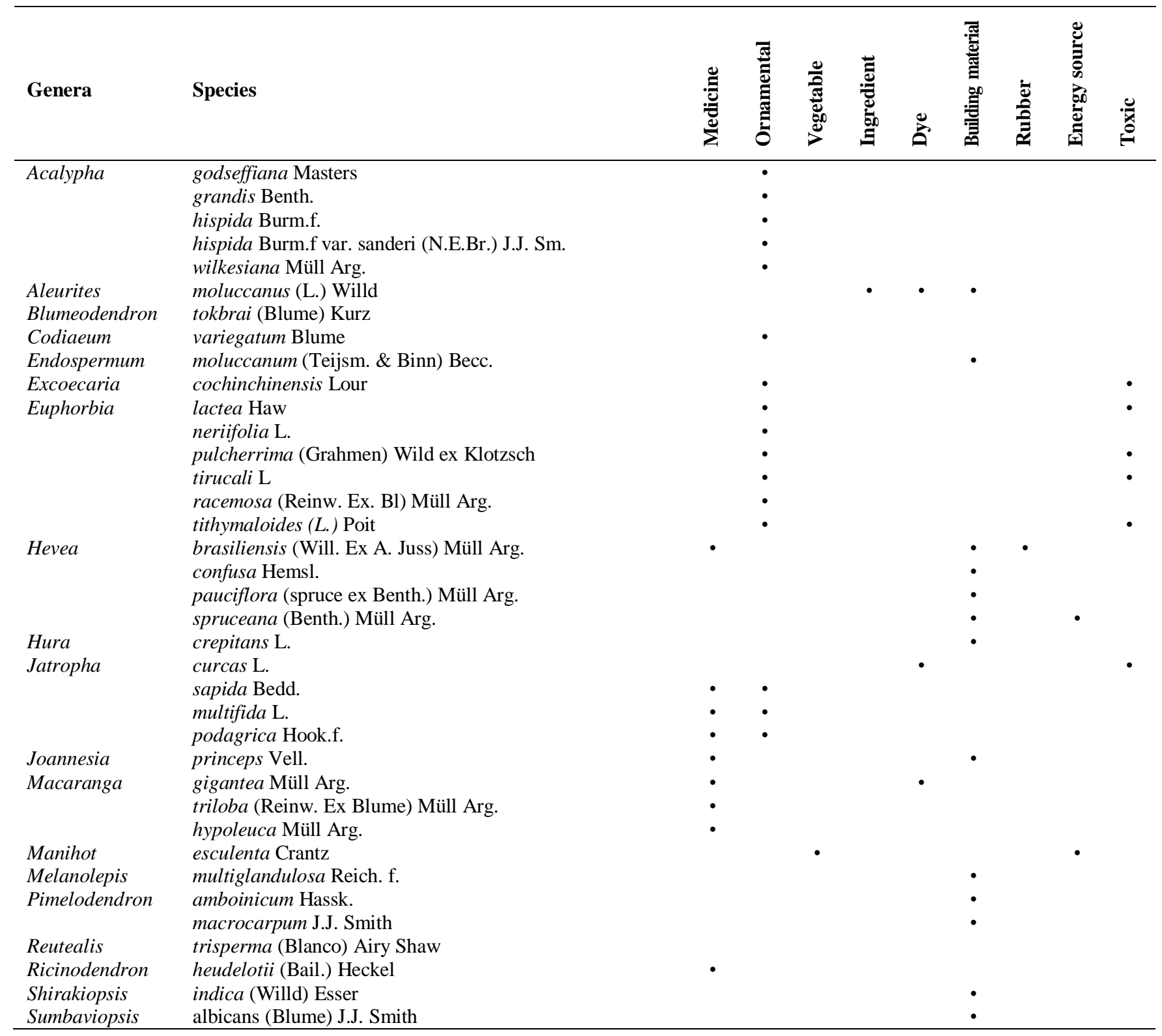

Table 4. The usage of Euphorbiaceae family as traditional medicines

\begin{tabular}{|c|c|c|c|}
\hline Species & Diseases & Material used & Usage \\
\hline Acalypha wilkesiana Müll Arg. & Eczema & Leaf & Rubbed \\
\hline Hevea brasiliensis (Will. ex A. Juss) Müll Arg. & Eczema, stroke, and rheumatic & Leaf & Rubbed or boil \\
\hline \multirow[t]{2}{*}{ Jatropha curcas L. } & Wounds and toothache & Stem sap & Rubbed \\
\hline & & Leaf stalk sap & Dripped \\
\hline \multirow[t]{2}{*}{ Jatropha gossypifolia $\mathrm{L}$. } & Wounds, eczema, hives, and & Sap & Rubbed \\
\hline & diarrhea & Root & Boil \\
\hline \multirow{2}{*}{ Jatropha multifida $\mathrm{L}$. } & Wound, swelling, eczema, and & Sap & Rubbed \\
\hline & digestive disorders & Root & Boil \\
\hline Jatropha podagrica Hook. f. & Gout, fish poison & Sap & Rubbed and diluted \\
\hline \multirow[t]{2}{*}{ Joannesia princeps Vell. } & Wound and hives & Stem bark & Mashed \\
\hline & & Oilseed & Rubbed \\
\hline Macaranga gigantea Müll Arg. & Wound and swelling & Root bark & Pounded or rubbed \\
\hline Macaranga triloba (Reinw. ex Blume) Müll Arg. & Acne & Leaf & Mashed, rubbed \\
\hline Macaranga hypoleuca Müll Arg. & Fever & Bark, root, young twig & Mashed, rubbed \\
\hline Ricinodendron heudelottii (Baill.) Heckel. & Acne & Bark & Boil \\
\hline
\end{tabular}




\section{Ornamental plant}

It is recorded that 16 species of Euphorbiaceae collections at the BBG have potential as ornamental plants and also as hedges, namely Acalypha godseffiana, A. grandis, A. hispida, A. hispida var. sanderi, A. wilkesiana., Codiaeum variegatum, Excoecaria cochinchinensis, Euphorbia lactea forma cristata, E. neriifolia, $E$. pulcherrima, Euphorbia tirucali, E. racemosa, E. tithymaloides, Jatropha multifida., J. podagrica and J. Sapida. As already known that several Acalypha species have an economic value notably in Malesia. Both $A$. hispida and $A$. wilkesiana are widely cultivated as ornamental plants in South East Asia. Brown-leaved or variegated specimens of $A$. wilkesiana are popular and often grown as hedges, whereas A. hispida is preferred for its very red pistillate inflorescences (Sagun et al. 2010).

\section{Ingredients and vegetables}

Two species of the Euphorbiaceae family have been recognized as food ingredient and as vegetable, namely Manihot esculenta and Aleurites moluccanus, respectively (Adhil et al. 2019). A. moluccanus (candlenut) has long been used as a spice. However, this species seems less popular nowadays, even though some communities are still cultivated it in their gardens, yards, or in agroforestry areas, particularly in eastern parts of Indonesia: Maluku, Nusa Tenggara Timur, and Nusa Tenggara Barat, for instance. However, candlenut has been household income generated for these communities (Purwanto and Cosiaux 2016).

\section{Natural dyes}

At least three species which are cultivated at the BBG can be used as natural dyes, notably for woven cloth, namely Aleurites moluccana, Macaranga gigantea, and Jatropha curcas. Yellow color can be obtained from the pulp of flesh fruit of $A$. moluccana, whereas green color is obtained from the leaf of M. gigantea (Seran and Hana 2018). Meanwhile, a green color is gained from a leaf of $J$. curcas and black color is obtained from its seeds (Hariyanto 2017).

\section{Building materials (timbers)}

There are 14 species of the Euphorbiaceae collections at the BBG that can be used as timbers, namely Aleurites moluccanus, Endospermum moluccanum, Hevea brasiliensis, $H$. confusa, $H$. pauciflora, $H$. spruceana, Hura crepitans, Joannesia princeps, Melanolepis multiglandulosa, Pimelodendron macrocarpum, Shirakiopsis indica, and Sumbaviopsis albicans. The timbers are utilized, notably local communities, to build a hut or a shelter in their gardens. Mostly are used as poles, building frames, or boards. Even though it is lesser-known timbers; however, it could substitute the commercial timbers for building due to limited availability. Aleurites moluccanus, Endospermum moluccanum, Hevea confusa, H. pauciflora, Pimelodendron amboinicum, and Sumbaviopsis albicans are among timbers species in Euphorbiaceae family that are usually utilized for roof, roof-truss, post, and pillar (Martawijaya et al. 2005;
Soerianegara and Lemmens 1994; Lemmens et al. 1995; Sosef et al. 1998). On the other hand, Hevea spruceana, Hura crepitans, Joannesia princeps, Melanolepis multiglandulosa, Pimelodendron macrocarpum, and Shirakiopsis indica are used for boards (Sosef et al.1998).

\section{Poisonous plants}

Six species of the Euphorbiaceae possess poisonous sap, such as Excoecaria cochinchinensis, its sap can kill fish in a short time (Dalimarta 2007), Euphorbia lacteal has a perilous sap when gets into the eyes and the sap of Euphorbia tirucalli can be used as insecticide (Arneti and Putri 2016). Other species (Euphorbia tithymaloides and Jatropha gossypifolia) contain a fairly high toxin (Karyati and Adhi 2018). The other, Jatropha curcas, has been investigated primarily as a source of oil. The seed cake that remains after oil extraction is an excellent source of plant nutrients. However, the presence of high levels of toxic substances and anti-nutrients limits the further applications of $J$. curcas oil and meal. (Haas and Mittelbach 2000). $J$. curcas oil and its extract can exhibit insecticidal effects, pesticidal effects, and antimycobacterial activity and also offer the potential for snail-killing effects (Chumkaew et al. 2003; Makkar and Becker 2009; Diwani et al. 2009).

\section{Collections value of the Euphorbiaceae at the BBG Ecological value}

Several genera in the Euphorbiaceae family have an important role in terms of land rehabilitation and reforestation of degraded areas, such as Hevea, Hura, and Pimelodendron. The species in these genera well adapted to surrounding areas therefore reforestation activities increased. In addition, the species also provided ecosystem services value (an ability to absorb carbon dioxide). Moreover, from an aesthetic value, the species showed great beauty as ornamental plants.

\section{Economic value}

Usage value of a plant species is divided into direct and indirect where both are crucial for community life, particularly in providing the daily needs (Purwanto et al. 2011). In Euphorbiaceae, several species can be used as a commercial commodity due to a high aesthetic value. Those are from genera Acalypha, Codiaeum, Excoecaria Euphorbia, Jatropha for instance, which have been wide traded (Chandra and Sitanggang 2007; Karyati \& Adhi 2018).

The other species in Euphorbiaceae family is Manihot esculenta (cassava) that has been long time cultivated in Indonesia. It grows well from coastland up to mountain at an altitude of 1700 asl. This cassava can serve as a dessert or as main food during famine times. Besides, ethanol can be generated from its tuber and it becomes an industrial product (Prihandana et al. 2007). Another species is candlenut (Aleurites moluccana), which is native to Indonesia, notably in Maluku Islands and eastern part of Indonesian archipelago. It has been well-known since Dutch Era and became one of popular spices and medicine as well. It is easy to propagate by using polyculture in 
agroforestry system or mixed cropping. Besides, it is an excellent species for reforestation and rehabilitation of degraded land purposed.

The usage of Euphorbiaceae plant species as traditional medicine has long been used by Indonesian communities, in particular, to deal with daily health problems. The communities usually grow various kinds of medicinal plants in their gardens. Consequently, supply of these raw materials is easily available and less health costs.

\section{Development of Euphorbiaceae collections at the BBG}

As an ex-situ conservation institution, BBG has to fulfill and maintain its collections properly. However, just maintaining the collections is not sufficient effort without exploring their potential values whether as ornamental plants or others. The genera Acalypha, Jatropha, Aleurita, Hura, Macaranga, and Ricinodendron for instance, are among potential genera as ornamental plants in Euphorbiaceae family. Species in those genera then selected for development and propagation purposes and would make a worthwhile contribution to the communities. Several Indonesian native species, Aleurites moluccana for example, have been widely developed as a spice. Others are also propagated for reforestation and rehabilitation in land degradation.

\section{Conservation}

Plant conservation activity takes priority over any other tasks of the BBG, furthermore, research, and domestication are followed. Cultivation, propagation, and maintenance of the collections is a form of conservation activities including the Euphorbiaceae collections at the BBG as well. To increase the collections, therefore, the exploration activities have to continuously carry out throughout Indonesian forests every year, which is recommended.

In conclusion, the Euphorbiaceae family has been segregated into five families viz. Phyllanthaceae, Putranjivaceae, Pandanaceae, Picrodendraceae, and Euphorbiaceae. Four of them are found at the BBG except for Picrodendraceae. Currently, the Euphorbiaceae collections at the BBG are classified into 39 genera and 136 specimens where 91 specimens are trees, 38 specimens are shrubs, three specimens are climbers and four specimens are succulents. Mallotus philippensis (Lam.) Mull. Arg. forma mollis was firstly introduced to BBG in 1922, originated from Philippines. Various species in Euphorbiaceae family can be utilized as traditional medicine (11 species), ornamental (16 species), spices and vegetables (two species), rubbers (one species), timbers (14 species), source of energy (two species), and toxics (six species). Euphorbiaceae collections have been successfully cultivated at the BBG. This proved that BBG has been carried out an ex-situ conservation very well.

\section{REFERENCES}

Adhil, Iqbal M, Ramadanil. 2019. Study of ethnobotany family Euphorbiaceae used by Pekurehua Tribe in Wuasa and Kaduwaa, North Lore, Poso, Central Sulawesi. Nat Sci: J Sci Technol 8 (1): 51 60 .
Anonymous. 2020. Jatropha podagrica. The Plant List. WWW. Theplantlist.org.

Arneti KH, Putri NK. 2016, Aktivitas ekstrak heksan tumbuhan patah tulang Euphorbia tirucalli (Euphorbiaceace) terhadap telur Crocidolomia pavonana (Lepidoptera: Crambidae). Prosiding Seminar Nasional Masyarakat Biodiversitas Indonesia 2 (1): 1-6. ISSN: 2407-8050 DOI: 10.13057/psnmbi/m020101. [Indonesian]

Baboo B, Sagar R, Bargali SS, Verma H. 2017. Tree species composition, regeneration and diversity of an Indian dry tropical forest protected area. Trop Ecol 58 (2): 409-423.

Bargali K, Josh B, Bargali SS, Singh SP. 2014. Diversity within oaks. Int Oaks 25: 57-70.

Bargali K, Joshi B, Bargali SS, Singh SP. 2015. Oaks and the biodiversity they Sustain. Int Oaks 26: 65-76.

Bargali SS. 1994. Forest floor development in Eucalyptus tereticornis Sm. plantations in a part of Central Himalayan tarai belt. Range Manage Agrofor 15 (1): 61-68.

Bargali SS. 1995. Efficiency of nutrient utilization in an age series of Eucalyptus tereticornis plantations in the tarai belt of Central Himalaya. J Trop For Sci 7 (3): 383-390.

Bargali SS. 1996. Weight loss and nitrogen release in decomposing wood litter in an age series of eucalypt plantation. Soil Biol Biochem 28: 699-702.

Bargali SS, Singh RP, Singh SP. 1992. Structure and function of an age series of eucalypt plantations in Central Himalaya, II. Nutrient dynamics. Ann Bot 69: 413-421.

Bargali SS, Singh RP, Singh SP. 1993. Pattern of weight loss and nutrient release in decomposing leaf litter in an age series of eucalypt plantations. Soil Biol Biochem 25: 1731-1738.

Bargali SS, Singh RP. 1997. Pinus patula plantations in Kumaun Himalaya. II. Nutrient dynamics. J Trop For Sci 10 (1): 101-104.

Batin CB, Carandang WM. 2010. Fruit color as an indicator of seed germination and seedling performance of Jatropha curcas. International Conference of Information System For the Agricultural Science and Technology, Univ. Los Banos, College, Laguna, Philippines. [Philippines]

Capobianco RA, Vestena S, Bittencourt AHC. 2009 Allelopathy of Joannesia princeps Vell. and Casearia sylvestris $\mathrm{Sw}$. on the cultivated species. Braz J Pharmacog 19 (4): 924-930. [Portuguese]

Chandra L, Sitanggang M. 2007. Pesona Puring. Agro Media Pustaka, Jakarta. [Indonesian]

Chumkaew P, Karalai C, Ponglimanont C, Chantrapromma K. 2003. Antimycobacterial activity of phorbol esters from the fruits of Sapium Indicum. J Nat Prod 66: 540-543.

Dalimarta S. 2007. Atlas Tumbuhan Obat Indonesia. 3. Puspa Swara, Jakarta. [Indonesian]

Diwani GE, Rafie SE, Hawash S. 2009. Antioxidant activity of extracts obtained from residues of nodes leaves stem and root of Egyptian Jatropha curcas. Afr J Pharm Pharmacol 3: 521-530.

Djarwarningsih T. 2007. Jenis-Jenis Euphorbiaceae (Jarak-Jarakan) yang Berpotensi sebagai Obat Tradisional. Puslit Biologi-LIPI, Cibinong. [Indonesian]

Fayed AA, Soliman M, Faried A, Hassan M. 2019. Taxonomic evaluation of Euphorbiaceae sensu lato with special reference to Phyllanthaceae as a new family to the flora of Egypt. Biol Forum-Intl J 11 (1): 47-64.

Gotep JG, Agada G, Gbise DS, Chollom S. 2010. Antibacterial activity of ethanolic extract of Acalypha wilkesiana. Afr Sci 11: 85-89.

Haas W, Mittelbach M. 2000. Detoxification experiments with the seed oil from Jatropha curcas L. Ind Crop Prod 12: 111-118.

Hariyanto F. 2017. Study plant diversity potential as natural batik dyes in Sidomulyo Village, Ampel District, Boyolali Regency. Biology Education Program, Faculty of Teacher Training and Education, Muhammadiyah University, Surakarta. [Indonesian]

Hendrian R, Witono JR. 2011. Pengantar Perkebun-Rayaan. Pusat Konservasi Tumbuhan Kebun Raya Bogor, Lembaga Ilmu Pengetahuan Indonesia. [Indonesian]

Hermann TM. 2006. Indigenous knowledge and management of Araucaria araucana forest in the Chilean Andes: implication for native forest conservation. Biol Conserv 15: 647-662.

IUCN. 2001. IUCN Red List Categories and Criteria: Version 3.1. Gland, Switzerland and Cambridge, UK. Online at http://www. iucnredlist.org/info/categories_criteria2001

Karki H, Bargali K, Bargali SS, Vibhuti, Rawat YS. 2017. Plant diversity, regeneration status and standing biomass under varied degrees of disturbances in temperate mixed oak-conifer forest, Kumaun Himalaya. Intl J Ecol Environ Sci 43 (4): 331-345. 
Karyati, Adhi MA. 2018. Jenis-Jenis Tumbuhan Bawah di Hutan Pendidikan Fakultas Kehutanan Universitas Mulawarman. Mulawarman University Press, Samarinda. [Indonesian]

Lemmens RHMJ, Soerianegara I, Wong MC (eds) 1995. Plant Resources of South-East Asia No 5(2) Timber Trees: Minor Commercial Timbers Prosea Foundation, Bogor, Indonesia. [Indonesian]

Makkar HPS, Becker K. 2009. Jatropha Curcas, a promising crop for the generation of biodiesel and value-added coproducts. Eur J Lipid Sci Technol 111: 773-787.

Martawijaya A, Kartasudjana I, Mandang YI, Prawira SA, Kadir K. 2005. Atlas Kayu Indonesia Jilid II. Pusat Penelitian dan Pengembangan Hasil Hutan, Bogor. [Indonesian]

Mourya NR, Bargali K, Bargali SS. 2019. Effect of Coriaria nepalensis Wall. colonization in a mixed conifer forest of Indian Central Himalaya. J For Res 30 (1): 305-317.

Oduola T, Adeosun GO, Avwioro GO, Oyeniyi MA. 2005. Mechanism of action of Jatropha gossypifolia stem latex as a haemostatic agent. Eur J Gen Med 2 (4): 140-143.

Ogundare AO. 2007. Antimicrobial effect of Tithonia diversivolia and Jatropha gossypifolia leaf extracts. Trend Appl Sci Res 2: 145-150.

Peng TY, Mat DM, Ujang S. 2011, Assessment of the properties, utilization and preservation of rubberwood (Hevea brasiliensis): a case study in Malaysia. J Wood Sci 57 (4): 255-266.

Polosakan R. Alhamd L. 2012. Keanekaragaman dan komposisi jenis pohon di Hutan Pameumpeuk-Taman Nasional Gunung Halimun Salak, Kabupaten Sukabumi. Edisi Khusus Hari Bumi. TNGHS, Sukabumi. [Indonesian]

Prihandana R, Noerwijayati PG, Adinurani, Setyaningsih D, Setiadi, Hendroko R. 2007. Prospek Pengembangan Industri Bioethanol dari Ubi Kayu: Bahan Bakar Masa Depan. PT. Agro Media Pustaka, Jakarta. [Indonesian]

Purwanto Y, Cosiaux A. 2016. Studi sistem pertanian tradisional masyarakat Saleman, Seram Utara, Maluku Tengah. Laporan Project Colupsia. CIRAD ann UNI EROPA, Bogor, Indonesia. [Indonesian]

Purwanto Y, Saparita R, Munawaroh E. 2011. Keanekaragaman jenis hasi hutan non kayu berpotensi ekonomi dan cara pengembangannya di
Kabupaten Malinau. Pusat Penelitian Biologi-LIPI, Balai Besar Pengembangan TTG-LIPI, Pusat Konservasi Tumbuhan dan Kebun Raya-LIPI. LIPI Press, Jakarta. [Indonesian]

Rahman AHMM, Akter M. 2013. Taxonomy and medicinal uses of Euphorbiaceae (Spurge) Family of Rajshahi, Bangladesh. Res Plant Sci 1 (3): 74-80. DOI: 10.12691/plant-1-3-5

Sagun VG. Levin G.A. Welzen VPC. 2010. Revision and phylogeny of Acalypha (Euphorbiaceae) in Malesia. Blumea 55: 21-60.

Sari R, Ruspandi, Ariati SR. 2010. An Alphabetical List of Plant Species Cultivated in the Bogor Botanic Gardens. Center for Plant Conservation Bogor Botanic Gardens - LIPI, Bogor. [Indonesian]

Seran W, Hana YW. 2018. Weaving cloth coloring plant identification in Kaliuda Village Pahunga Lodu, East Sumba. Jurnal Agribisnis Perikanan 11: 1-8. [Indonesian]

Singh JS. 2002. The biodiversity crisis: A multifaceted review. Curr Sci 82: 638-647.

Soerianegara I, Lemmens RHMJ (eds) 1994. Plant Resources of SouthEast Asia No 5(1) Timber trees: Mayor Commercial Timbers. Prosea Foundation, Bogor, Indonesia.

Sosef MSM, Hong LT, Prawirohatmojo S (eds.) 1998. Plant Resources of South-East Asia No 5 (3) Timber trees: Lesser-known timbers. Prosea Foundation, Bogor, Indonesia. [Indonesian]

Tchoundjeu Z, Atangana AR. 2006. Ricinodendron heudeloti Southampton Centre of Underutilized Crops. Southampton University, Southampton, UK.

UNEP. 2001. Executive Summary. In: India: State of the Environment Report. UNEP-TERI-MEOEF, New Delhi.

Webster GL. 1994. Classification of the Euphorbiaceae. Ann Mo Bot Gard 81: 3-32.

Wurdack KJ, Hoffmann P, Samuel R, De Bruijn A, Van Der Bank M, Chase MW. 2004. Molecular phylogenetic analysis of Phyllanthaceae (Phyllanthoideae Pro Parte, Euphorbiaceae Sense Lato) using plastic RBCL DNA sequences. Am J Bot 91 (11): 1882-1900. 